\title{
DISCUSSION.
}

This department has been established by the editors in order to afford to those interested in questions relating to economic geology an opportunity for informal discussion. Contributions are cordially invited either in the form of discussion of more formal papers appearing in earlier numbers or bearing upon matters not previously treated. Letters should be directed to the Editor, Sheffield Scientific School of Yale University, New Haven, Conn. The full name of the author should be attached to all communications.

\section{A CONVENIENT LOOSE-LEAF SYSTEM FOR FIELD MAPS AND NOTES.}

Sir: Having benefited in numerous instances from the descriptions and discussions of practical field and office methods which have appeared from time to time in Economic GEology, and in the hope that others may find it useful, the writer is impelled to describe a system for field maps and notes which, after several years' use, he has found to have many advantages.

Some of the advantages of the system are: (I) It permits both maps and notes to. be carried in the same container, a $5 \times 8$ inch clutch binder which fits readily into the pocket. (2) It preserves the maps from the wear and soiling to which field maps are usually subjected. A map at the end of a field season is in almost as good condition, physically, as at the beginning. (3) It permits ready cross-reference between map and notes without burdening the former with reference marks. (4) Both maps and notes may be assembled in permanent loose-leaf binders and classified and arranged in any way desired.

The equipment consists of (I) a $5 \times 8$ inch clutch binder, preferably hinged only on the front cover and opening along the 5 -inch side; (2) one or more loose-leaf binders for $5 \times 8$ inch paper, punched along the 5 -inch side; (3) a supply of loose-leaf coördinate paper. That which the writer is using is ruled into one sixth inch squares, but one tenth inch would, perhaps, serve just as well. 
Below is a description of the method of using the system where one of the U. S. Geological Survey topographic sheets is being used as a base map:

The map is first cut into nine sections along the parallels and meridians. These sections fit readily into the note book. Each section is mounted on a sheet of ruled loose-leaf paper in such a way that the top and left-hand sides coincide with ruled lines on the paper. Glue or rubber cement may be used for mounting. The latter has the advantage that it does not cause buckling and is not affected by water.

The sections of the map are designated by an initial letter or abbreviation for the name of the sheet and a number for each of the nine sections, numbered from left to right from the top down. Thus the upper right-hand section of the Atoka sheet would be "A 3." The lower left-hand section would be "A 7." This designation is placed at the lower right-hand corner of the sheet.

On the side margins of the loose-leaf sheets, outside the map, the squares of the cross-section paper are numbered from the top down. Only every fifth number, I.5.IO, etc., is actually set down. This furnishes one of the coördinates for locating positions on the map. The other is furnished by a "cover sheet," which is simply a blank sheet of the coördinate paper, along the bottom of which the coördinate squares are lettered from left to right, beginning about as far from the left-hand margin as is the left-hand edge of the map.

In practice the sheet carrying the section of the map to be used is placed in the front of the binder with the cover sheet over it. The notes may be conveniently kept in the back of the binder, together with sections of the map not in immediate use. To make reference to a location on the map it is only necessary to slip the cover sheet up until its lower edge is on the point desired and is parallel to the lower edge of the map. Then, if the zero of the lettering of the cover sheet be placed at the left-hand margin of the map, the coördinates can be instantly determined. The location is recorded in the notes as "A 3 , 1о j," "A 7, 26p," 
etc. This gives the location to the nearest one sixth inch square without making any mark upon the map. If closer location is necessary, a dot on the map may be used. Even a small dot can readily be found at any time by reference to the coördinates of the imaginary square in which it occurs.

In the office the location of any point referred to in the notes can be instantly found, even on an uncut map, by lettering and numbering a card to correspond with the coördinates used in the field and using the parallels and meridians as guides for the various sections.

The method here described is applicable to other sizes of maps and loose-leaf note books, but there are important advantages in standardizing on one size. The $5 \times 8$ inch is probably the most convenient. Irregular sized maps can be cut into sections and used in the same way as the U. S. maps.

Inasmuch as paper is much cheaper than a geologist's time, it is a great advantage to use a separate sheet of paper for each note, even if it is only a few words. If this is done, a season's work can be classified, arranged, and rearranged in any way that is most convenient. When a report is being written all the notes - on a particular location or topic can be quickly assembled even if the work of several seasons or of several men is involved. Full advantage of the loose-leaf principle is thereby gained.

HobarT, N. Y.

JoHN L. Rich.

\section{LOGAN'S EXPLANATION OF THE ORIGIN OF INDIANA'S "KAOLIN."}

Sir: In I9I9 Mr. W. N. Logan, state geologist of Indiana, published a most interesting study of the halloysite deposits ${ }^{1}$ of Indiana to which Cox in 1874 had applied the name "Indianite." In it he ascribes to anaërobic bacteria an essential rôle in the chain of reactions which resulted in the formation of the halloysite beds. His facts and conclusions may be summarized as follows :

${ }^{1}$ Logan, W. N., "Kaolin of Indiana," The Department of Conservation, State of Indiana, Publication No. 6, Indianapolis, 1919. 